\title{
En el 75 aniversario de la muerte de Dietrich Bonhöeffer
}

\author{
ENRIQUE SOMAVILLA RODRÍGUEZ ${ }^{1}$
}

RESUMEN: Si la vida de Dietrich Bonhöeffer, pastor de la Iglesia luterana, fue más bien breve, su obra, por el contrario, fue amplia e influyente. Hombre de profunda fe con un compromiso social y político inquebrantable. De amplia cultura y gran viajero, estuvo en España, Estados Unidos, Gran Bretaña, Suiza, Dinamarca, Suecia, etc. También fue miembro de la Iglesia Confesante y llevó adelante la participación de la Iglesia en el movimiento ecuménico. Acusado de distintos cargos: cuestiones económicas, oposición al régimen nacionalsocialista y traición al Führer, pasó por la prisión de Tegel y la del servicio de seguridad y policía de la Gestapo, en Berlín. Posteriormente fue enviado al campo de concentración de Buchenwald y después al de Flossenbürg. Fue ejecutado en la horca el 9 de abril de 1945.

${ }^{1}$ Es doctor en Teología Dogmática y en Derecho, licenciado en Estudios Eclesiásticos, Máster en Doctrina Social de la Iglesia, Máster en Relaciones Internacionales y Protocolo, Máster en Derecho de la Unión Europea, Diploma de Estudios Avanzados en Derecho (DEA). Es Profesor ordinario de Teología en el Centro Teológico San Agustín CTSA (afiliado a la Pontificia Universidad de Salamanca), donde imparte diversas asignaturas: Análisis Político y Económico, Sacramentos de Iniciación cristiana, Misterio de Dios, Cristología, Iglesias Orientales, Ecumenismo, Doctrina social de la Iglesia. Profesor de Teología cristiana de las religiones: relaciones interreligiosas, Teología de la Comunicación, en el Estudio Teológico Agustiniano de Valladolid ETAV (Centro Agregado a la Facultad de Teología del Norte, sede de Burgos). Profesor de Derecho Eclesiástico del Estado en El Real Centro Universitario Escorial-María Cristina, en San Lorenzo de El Escorial (Madrid) adscrito a la Universidad Complutense y Profesor del Master de Protocolo en la Facultad de Derecho de la UNED. 
Palabras Clave: Bonhöeffer, Iglesia Confesante, Nacionalsocialismo, Ecumenismo, Judaísmo.

ABSTRACT: TIf life Dietrich Bonhöeffer, pastor of the Lutheran Church, was rather brief, his work, conversely, was broad and influential. Man, of deep faith with a social commitment and unshakable politician. Wide culture and great traveler, was in Spain, United States, Great Britain, Switzerland, Denmark, Sweden, etc. He was also a member of the Confessing Church and carried out the participation of the Church in the ecumenical movement. Accused of different charges: economic issues, opposition to the national socialist regime and betrayal of the Führer, passed through Tegel prison and thesecurity service and Gestapo police, in Berlin. Later was sent to the Buchenwald concentration camp and then the Flossenbürg. He was executed by hanging on April 9, 1945.

Keywords: Bonhöeffer, Confessing Church, National Socialism, Ecumenism, Judaism.

\section{Introducción}

Casi dos meses antes del asesinato de Dietrich Bonhöeffer, en el campo de concentración de Flossenbürg en suelo alemán, una de las ciudades más artísticas, culturales y hermosas que tenía Alemania, la famosa Dresde o Dresden como suele aparecer en muchos de los tratados de geografía, perecía bajo la masa de bombas incendiarias y explosivas, descargadas por las fuerzas áreas norteamericana y británica. La capital de Sajonia, conocida como la Florencia del norte desaparecía ante los ojos de sus habitantes y de todos los que se habían ido refugiando paulatinamente tras la caída del frente oriental, en la medida que las fuerzas soviéticas penetraban en suelo alemán. Dresde había conocido a lo largo del transcurso de la guerra el ulular desconcertante de las sirenas antiaéreas, en diversas ocasiones, pero en la inmensa mayoría de las mismas, fueron falsas alarmas, pues a excepción de algunas bombas, caídas por despiste, la ciudad se mantuvo en pie sin demasiados peligros, pues de todos salía conjurada, al ser de una belleza sinigual. Muchos alemanes creyeron firmemente que se salvaría de un masivo bombardeo, como lo habían tenido otro sinfín de ciudades ya bien machacadas por los Aliados. Se trataba de una ciudad sin grandes objetivos militares, lo único que se mantenía era 
el ser un nudo de comunicaciones con el este-oeste, pues el norte-sur ya era casi impracticable. Pero este tema quedaba fuera de toda tentativa, pues el derrumbe general ante la presión soviética, desde el este, era ya abrumador. Pero el Elba se teñiría de rojo ante el dantesco espectáculo de luz y fuego que asolaría toda la ciudad. La iluminación con las bengalas de color rojo y verde, sumirían a la famosa ciudad en el presagio de una noche desastrosa De ciudad apacible y señorial, se convirtió de la noche a la mañana, nunca mejor dicho, en uno de los mayores dramas y una de las masacres más aberrantes de la historia contemporánea. La noche del 13, martes de carnaval, al 14 de febrero, miércoles de Ceniza y el día 15, se les conoce como las jornadas del oprobio, de la indecencia y la inhumanidad de la guerra total: la pérdida de vidas humanas fue cuantiosa, aunque no todas las versiones se ponen de acuerdo ${ }^{2}$, las cifras oscilan desde 30.000 a 40.000 víctimas. La propaganda alemana en principio la había situado en cientos de miles. Por eso resulta tan difícil establecer unas cifras reales. En definitiva, y a pesar de que los ataques nocturnos no habían apuntado directamente sobre las fábricas de armamento existentes, que se situaban en el extrarradio de Dresde, se llegó a destruir prácticamente el $85 \%$ del tejido industrial de la ciudad y colapsó las infraestructuras esenciales para el adecuado funcionamiento de la misma, haciendo inviable y mínima administración para reactivar los imprescindibles servicios que eran necesarios.

\section{Biografía de Dietrich Bonhöeffer: contexto familiar}

Dietrich había nacido en el seno de una familia aristocrática, intelectual y liberal ${ }^{3}$. A pesar de carácter poco religioso de su entorno familiar ${ }^{4}$, Bonhöeffer decidió, en 1923, iniciar sus estudios de teología en Tübingen, Berlín. Después de tres años de estudio en la Universidad de Berlín, de 1924 a1927, escribió su disertación, Sanctorum Communio, obteniendo su

${ }^{2}$ Cf. F. TAYlor, Dresden: Tuesday, February 13, 1945, Nueva York 2004, 354.

${ }^{3}$ Cf. G. Kretschmar, "Dietrich Bonhöeffer (1906-1945)", en H. FrIES - G. KretsCHMAR (EDS.), Klassiker der Theologie II, Munich 1983, 376-403.

${ }^{4}$ Cf. G. Hourdin. Bonhöeffer. Una Iglesia para mañana, Madrid 1972, 17-18. 
doctorado con la máxima calificación ${ }^{5}$. Durante el curso 1929-1930, estuvo en Barcelona ${ }^{6}$, a cargo de una Congregación luterana alemana, recorriendo toda España y conociendo su cultura. Durante el curso 1930-1931 realizó un seminario de postdoctorado en Estados Unidos de la Unión Teológica en Nueva York, regresando de nuevo a la Universidad de Berlín como profesor de teología sistemática a partir de 1931, tras defender la tesis Acto y ser, que le permitía acceder a las clases en la universidad. Participó activamente en el movimiento ecuménico europeo. Pronto los acontecimientos hicieron que comenzara su actividad política dentro y fuera de la Iglesia. La llegada al poder del partido nacional-socialista alemán, es decir nazis, el 30 de enero de 1933, supuso un cambio en las expectativas de Dietrich.

A partir del otoño de 1933, comenzó a significarse ayudando a organizar la Liga de Emergencia de los Pastores alemanes. Asumiría posteriormente como pastor de la Iglesia Evangélica Alemana. Salió hacia Gran Bretaña, trabando muchas amistades como la del obispo George Bell y participando en la Iglesia Reformista de San Pablo en Londres. Durante la primavera de 1934 se organizó la Iglesia Confesional en Barmen en Alemania, y en 1935 fue requerido para que se hiciese cargo del Seminario que estaba en Zingst, trasladado posteriormente a Finkenwalde en Pomerania. Su estancia en Inglaterra tocaba a su fin ${ }^{7}$. Hombre abierto, cosmopolita, muy sincero, claro, determinante, fuerte, comprometido, audaz y ante todo libre. Como consecuencia de la situación política en el Reich alemán, surge la Iglesia Confesante, la cual mantenía que el nacionalsocialismo nazi, con toda su ideología racista, era del todo incompatible con el cristianismo. Dietrich insistiría, sin que le temblara el pulso, en la libertad de predicar la Buena Nueva del Evangelio e incluso arriesgar la vida en defensa de los judíos, puesto que todo cristiano debería de estar dispuesto a ello. Ante estas actitudes, Bonhöeffer, perdió a partir de agosto de 1936, la enseñanza en la Universidad de Berlín. A

${ }^{5}$ Cf. E. H. Robertson, Dietrich Bonhöeffer. Introducción a su pensamiento teológico, El Paso (Texas) 1975, 17.

${ }^{6}$ Cf. J. J. Alemany, “La teología barcelonesa de Dietrich Bonhöeffer”, en Estudios Eclesiásticos 49 (1974) 59-77.

${ }^{7} \mathrm{Cf}$. http://www.raoulwallenberg.net/es/salvadores/otros/dietrich-bonhoeffer-pastor/ Visto 06-04-2020. 
pesar de todos los contratiempos, siguió con el plan de formación de los pastores en la Iglesia Confesante. En 1940, se le prohibió dictar conferencias y en 1941 todas las publicaciones. Se dedicó a viajar y por medio de sus contactos ecuménicos pudo mantener una serie de conversaciones con las potencias aliadas como fue su viaje a Estocolmo en la primavera de 1942, conectando con la Oficina Extranjera Británica. Ofreció acciones concretas del círculo de resistencia del que era partícipe. No tuvieron demasiado éxito, pues la suspicacia y desconfianza de las autoridades Aliadas no facilitaron el gran esfuerzo hecho por Dietrich Bonhöeffer para conseguir una paz inmediata. En la primavera de 1943, fue encarcelado por las actividades sobre fraudes monetarios ${ }^{8}$, conspiración y traición al Estado. En un principio fue arrestado en Tegel hasta primeros de octubre de 1944 que fue enviado a la sede central de la policía política de la Gestapo en Berlín. Disponía de libros y posibilidades para escribir. Poco a poco, a medida que las investigaciones fueron progresando, apareció la implicación de Dietrich en el intento de asesinato del Führer el 20 de julio de 1944. El 7 de febrero de 1945 fue llevado al campo de concentración de Buchenwald y después al de Flossenbürg. Como teólogo ${ }^{9}$, las ideas de Bonhöeffer y su discusión sobre un cristianismo laico, reforzadas por su propio martirio, ejercieron una gran influencia sobre el pensamiento protestante de posguerra ${ }^{10}$.

\section{Dietrich Bonhöeffer: el hombre}

En Bonhöeffer existen dos preguntas fundamentales a las que es preciso responder. La primera es ¿Quién es Jesucristo? la segunda es ¿Qué es la Iglesia? Pero las respuestas no se han de dar solo desde la razón, sino especialmente desde la implicación de la vida. La gran figura de este singular teólogo aparece, sin duda, en la revalorización de la memoria pro-

\footnotetext{
${ }^{8} \mathrm{Cf}$. http://www.iglesiapueblonuevo.es/index.php?codigo=bio bonhoeffer Visto 0704-2020.

${ }^{9}$ Cf. E. Bethge, Dietrich Bonhöeffer. Teólogo -cristiano- hombre actual, Bilbao 1970.

${ }^{10} \mathrm{Cf}$. http://www.raoulwallenberg.net/es/salvadores/otros/dietrich-bonhoeffer-pastor/ Visto 08-04-2020.
} 
vocativa de Jesús de Nazaret para plantear una propuesta eclesial que solo tiene sentido y relevancia histórica desde lo que él llama: el seguimiento de Jesús. La personalidad de Bonhöeffer ${ }^{11}$ tiene una proyección multidireccional: un hombre de fe, con todo lo que esa expresión significa; un hombre de oración, es decir un místico; un pastor luterano; un gran predicador y acreditado líder espiritual; un profesor carismático; un artista: excelente pianista y poeta; un filósofo y un teólogo de la vida; un militante político: precursor en buena medida de la teología de la realidad y un mártir:

Sus obras: El precio de la gracia y ¿Quién es y quién fue Jesucristo? constituyen el fundamento de un pensamiento que muchos han denominado Teología de la realidad: la realidad de la vida ${ }^{12}$, la realidad de la Iglesia dentro de la realidad del mundo, desde la realidad de un Dios que se ha revelado al mundo: El Verbo se hizo carne y habitó entre nosotros. La Iglesia no es para sí, decía Bonhöeffer, sino para el mundo. Es ahí donde creo que la aportación de este teólogo es relevante y diferencial por su pragmatismo. Es la historia del Evangelio como plasmación de la vida de Jesucristo $^{13}$. Sin duda, esta personalidad arrolladora se manifiesta en toda su actividad humana, social y emprendedora en todas las manifestaciones que mantiene muy a pesar de todas las dificultades que se le presentan. Posiblemente una de las claves será su compromiso desde la Iglesia Confesante Alemana. Con un grito a favor de las libertades, usurpadas por el régimen nazi, pero al mismo tiempo vinculadas desde lo más íntimo a la gloria de Dios ${ }^{14}$.

Este nuevo mártir de la Iglesia, pues no cabe duda que dio la vida por Cristo, supone un gran entrenamiento de su persona, ante todo lo que le podría llegar, como respuesta a su actitud beligerante con el régimen, a favor de los judíos y de todos los que se oponían a un sistema despótico que violaba sistemáticamente los derechos de las personas. Un hombre que se aventuró con Dios y expresó que estaba allí presente, donde otros

\footnotetext{
${ }^{11}$ Cf. H. Motтu, Dietrich Bonhöeffer, Paris 2002.

${ }^{12}$ Cf. Ch. Feldmann, Tendríamos que haber gritado. La vida de Dietrich Bonhöeffer, Bilbao 2008.

${ }^{13}$ Cf. R. MARLÉ, Dietrich Bonhöeffer, testigo de Jesucristo entre sus hermanos, Bilbao 1970.

${ }^{14}$ Cf. CH. MArsh, Extraña gloria. Vida de Dietrich Bonhöeffer, Madrid 2018.
} 
no le veían. Dios no había muerto ${ }^{15}$, Dios no había desaparecido de aquel horror, pues Dios estaba allí, en medio de ellos, crucificado. Dietrich Bonhöffer insistiría desde la prisión: "Hay que alimentar la fe en Dios y la conveniencia de su presencia precisamente desde el éxito humano, desde lo más positivo de la historia". Ese es el Dios que vale la pena, que merece confianza, que no dispensa a los seres humanos de sus responsabilidades históricas. En los estertores finales de la Segunda Guerra Mundial en Europa, antes de ser asesinado en el campo de concentración de Flossenbürg (Alemania) la mañana del lunes, 9 de abril de 1945 manifestó: Esto es el final, para mí el comienzo de la vida. La vida no terminaba, sino que empezaba para siempre ${ }^{16}$. Aparece como una excelsa figura del hombre nuevo de san Pablo, consciente de su propia realidad, de su existencia y con un gran profundo sentido de la vida. Hombre cabal, con un coraje impresionante, de una sola pieza, de una inmensa profundidad. Toma conciencia de sus grandes potencialidades y cualidades que Dios ha puesto en él y en toda la humanidad, en creyentes y no creyentes, y asumiendo la necesidad que todos necesitamos de todos. Reflexiona sobre la eventualidad de su muerte con la absoluta firmeza y la gran esperanza de que Dios no puede permitir que nuestra vida, que su vida, termine en fracaso. Es el amor espiritual, enraizado en Jesucristo, solo le sirve a Él y sabe que no hay otro acceso directo al prójimo. Al prójimo vamos por el único camino que es Cristo, que es mediador entre Dios y los hombres. Él posee certeza clara que no existe ningún otro posible atajo; que es preciso encontrarse con Dios en el camino de la realidad, de la existencia profunda del hombre, dolorido por el pecado. Bonhöffer fue un hombre muy adelantado a su tiempo. Reconocer todos los esfuerzos ecuménicos, realizados por él, son uno de los mejores testimonios de su compromiso con la Iglesia de Jesucristo. En unos tiempos tan convulsos, vivió una singularidad de circunstancias que le hicieron reflexionar como un auténtico hombre libre y de compromiso con la Iglesia.

Un hombre que apostó con todas sus fuerzas, por la dignidad del hombre, encarnada en la situación de persecución a la que estaban so-

${ }^{15}$ Cf. E. Colomer, Dios no puede morir. Una aproximación histórico-crítica a la teología radical, Barcelona 1970.

${ }^{16}$ Cf. G. Hourdin, Dietrich Bonhöeffer. Víctima y vencedor de Hitler, Bilbao 1995. 
metidos los judíos por el sistema político imperante en Alemania. Un hombre que buscó la implicación de la Iglesia luterana alemana en los conflictos de las relaciones con el Estado. Un hombre que buscó cauces de aproximación entre las Iglesias cristianas en Alemania, cuestiones que le llevarían hablar alto y claro de tales atrocidades y que pagaría con la vida, no sin antes atravesar su calvario personal. Si Cristo no se había quedado en el más allá, sino que vino y se encarnó en nuestra realidad, es decir, en el más acá, la Iglesia ha de encontrarse con Él, no en las fronteras del más acá con el más allá sino en el mismo centro del mundo. Pues Cristo tomó nuestra carne para redimirla, el que era Dios, se hizo hombre para perdonarnos, se hizo pecado, nosotros también debemos estar en medio del mundo para dar testimonio de la verdad. Y Dietrich la verdad la atestiguó con su muerte, colgado de la soga de una horca en el patíbulo del campo de concentración. Por eso la muerte de Dietrich Bonhöeffer parece como un lugar teológico privilegiado por cuanto que, última y radicalmente, da testimonio de la unidad de la vida y del pensamiento de un hombre comprometido con la vida, de un cristiano que vive ejemplarmente, la de un teólogo avanzado a su tiempo: él realiza en su existencia lo que él ya había reflexionado teológicamente ${ }^{17}$. En definitiva, un gran testigo de Jesucristo entre los hombres, que son sus hermanos, un hijo primordial de la Iglesia, comprometido con ella y anunciando que Cristo es el Señor. Una figura reivindicada por san Pablo VI, al que se refiere como una inmensa personalidad hondamente cristiana. La Iglesia ha de ser para el mundo, nunca para ella misma. La Iglesia ha de comunicarse con el mundo; es necesario que dialogue con el mundo. Idea primordial de la convocatoria conciliar en 1958. Pablo VI, trataría de la cuestión del diálogo en muchos de sus documentos como la encíclica Ecclesiam suam o en el Concilio Vaticano II, las constituciones Dei Verbum, Lumen gentiun y Gaudium et spes. Otra de las influencias en Pablo VI como Jacques Maritain.

${ }^{17} \mathrm{Cf}$. https://protestantedigital.com/opinion/35841/70-anos-de-la-muerte-de-bonhoeffer Visto 09-04-2020. 


\section{Dietrich Bonhöeffer: el filósofo}

Una de las proyecciones que tiene Dietrich Bonhöeffer va a ser la faceta de filósofo. Esta estará ligada a la teología. De ahí su obra Acto y ser: Filosofía trascendental y ontológica en la teología sistemática. Bonhöeffer utiliza una expresión muy popular, que expresaba: "hay que vivir estsi Deus non daretur, como si Dios no existiera". Esto, que nosotros podemos entender como algo negativo, le lleva a Bonhöeffer a una mayor reflexión y profundidad si no será ese el modo de poder descubrir a Dios $^{18}$, desde las diferentes perspectivas. Por eso, la visión de Dietrich Bonhöeffer, es de un intelectual protestante cuya reflexión cristiana puede ser aplicada a una materia aconfesional. Propone que el mundo ha llegado a ser adulto, por lo que se presentan diversas orientaciones que, por un lado, tergiversan la fe, y por el otro, generan un alejamiento de todo lo religioso. ¿No es precisamente esta breve descripción de la sociedad de mitad del siglo XIX un fuerte reflejo de la actualidad? Dietrich sigue su línea de amplia libertad. En respuesta a esta actitud, Bonhöeffer propone un cristianismo arreligioso, que no implica otra cosa sino una nueva concepción de Dios, de Cristo, de la Iglesia, del ser religioso, de la espiritualidad, en definitiva, de la trascendencia. Un cristianismo arreligioso significa el fin de la religión y de su "Dios". Pero háblese aquí de una religión que piensa a Dios como un deus ex machina utilizado para dar solución a problemas, como un mago que es capaz de curar todos los males de mundo, como un ser en quien me puedo librar de toda responsabilidad por las acciones que realice en la cotidianidad. Así pues, propone vivir no con la hipótesis de Dios, sino con la hipótesis de que no hay Dios; de "vivir delante de Dios y con Dios, pero sin Dios" ${ }^{19}$. Este pensamiento permite reconocer que debemos salir de los estereotipos de Dios o trascendencia que se nos han impuesto y velar por comunicar un mensaje liberador, que dé sentido a la vida y no lleve a la opresión o a la vivencia de una heteronomía espiritual y religiosa, en donde se sigue una determinada creencia, sin criticidad ni reflexión,

${ }^{18}$ Cf. E. Bueno dE LA Fuente, “Eberhard Jüngel: Dios es amor”, en Aula de Teología, Ciclo II: teólogos clásicos del siglo XX, Santander 22-02-2011

${ }^{19}$ R. Gibellini, La teología del siglo XX, Madrid 1993, 145. 
casi llegando al fundamentalismo. Esta visión de Bonhöeffer brinda entonces las pautas para un pensamiento reflexivo, centrada en lo esencial de la vida del hombre, que no es otra cosa que la espiritualidad y la trascendencia en sentido original ${ }^{20}$. Para Dietrich, tanto la filosofía social como la sociología se utilizarán como estudio para el servicio a la teología. En realidad, era él, el que se mostraba al servicio de los demás como expresión de su pensamiento. Su vocación espiritual se enmarcaba dentro de una mayor capacidad humanista, donde el hombre pensador entraba en el marco de la espiritualidad, pero con una carga de arreligiosidad. Era necesario preguntarse por la situación social que atravesaba el mundo, la sociedad. Así se necesitaba contestar a esa realidad y a las necesidades que atravesaba que, a su vez, estaban por encima de las preguntas de la teología ${ }^{21}$. El pensamiento estaba por encima y la reflexión debía de llegar a respuestas concretas y reales, más allá de las preguntas teológicas. El tiempo en España, siendo asistente de la comunidad Evangélica de Barcelona ${ }^{22}$ fue decisivo en su devenir intelectual y cultural, junto con la estancia americana en Nueva York ${ }^{23}$ que completará su ciclo social y filosófico. En Alemania vería el drama.

\section{Dietrich Bonhöeffer: el teólogo}

Los nuevos aires que trae su quehacer teológico suponen comprender en el fondo que en Dietrich Bonhöeffer su existencia va unida íntimamente a su experiencia vital: es decir, que su compromiso en la vida va unida al pensamiento y entre ellos suponen una amalgama indestructible, de tal manera que es muy difícil poder comprender toda su obra si no se conoce anteriormente todo su itinerario personal que le llevó a un final

${ }^{20} \mathrm{Cf}$. https://ciencia.lasalle.edu.co/cgi/viewcontent.cgi?article=1045\&context=lic educacion religiosa Visto 09-04-2020. Cf. A. CÁrdenas ACEro, Por una renovación pedagógica. Fundamentos de una educación neo religiosa escolar, Bogotá 2018, 50-51.

${ }^{21}$ Cf. CH. MArsh, Extraña gloria. Vida de Dietrich Bonhöeffer, Madrid 2018, 137 183.

${ }^{22}$ Cf. D. BonhöEfFER, Comunidad y promesa, Madrid 2018, 21-175.

${ }^{23}$ Frank Fisher, teólogo africano-americano, le llevó a conocer las Iglesias negras de Harlem en Nueva York. Le sedujo la música "espiritual negra” y dicha experiencia le llevó a defender a los judíos en su patria. 
dramático de su vida. Su obra teológica está planteada de la siguiente manera:

En primer lugar, hay que tener en cuenta: qué es la Iglesia y quién es Jesucristo. Hay que tener conocimiento de la sociología de la Iglesia. Así la obra Sanctorum Comunnio de 1927; quién es y quién fue Jesucristo de 1933; el precio de la gracia y el seguimiento de 1937 y vida en comunidad de 1938. Primera época.

En segundo lugar, nos encontramos con Ética y Compromiso político; Ética de 1940 y Resistencia y sumisión de entre 1943-1945. Segunda época.

Respecto a la llamada primera época: desde sus planteamientos eclesiológicos fundamentales, Dietrich Bonhöeffer estudiará la dimensión comunitaria de la Iglesia con el auxilio de las ciencias sociales: siempre estará presente la sociología. Pero es necesario tener en cuenta que no se trata de proceder a una investigación de índole sociológico. Sino más bien de una estructuración del orden dogmático mediante la ayuda de las ciencias y así conseguir el conocimiento más profundo para atisbar la existencia de la realidad eclesial desde el orden social que la sustenta. Pues la Iglesia para Dietrich es a la vez: esencial y visible. La dimensión esencial no se encuentra sino es desde la empiricidad de lo que ocurre. La Iglesia tiene una connotación espiritual, pero al mismo tiempo queda dominada por la realidad histórica. Por eso su manera de comprenderla es desde el fenómeno de los datos sociológicos. Su descripción suele ser en numerosas ocasiones como persona viva. La dimensión de Iglesia aparece en el hombre nuevo, creado por Dios siguiendo a Ef. 4,24: "A revestirnos del Hombre Nuevo, creado según Dios en la justicia y santidad de la verdad”. El Cristo crucificado y resucitado está en la Iglesia por la acción del Espíritu. Si bien Cristo que se encarnó permanece también en ese cuerpo que es la nueva humanidad. Tras la Ascensión de Jesús, el lugar de Cristo en el mundo es recogido en su cuerpo que es la Iglesia. Es, por tanto, Cristo presente mediante el Espíritu Santo. Aquella realidad empírica de la Iglesia es no solo aplicable a su dimensión de sociedad perfecta o mística, sino a las relativas a comunidad y comunión.

La trayectoria personal de D. Bonhöeffer, a diferencia de la de K. Barth, arranca en el mundo de la docencia y de la investigación para desembocar en el de la acción y el compromiso pastoral, ecuménico y, finalmente, político. "La espera inactiva y la contemplación apática no son 
actitudes cristianas" ${ }^{24}$. La aportación teológica de D. Bonhöeffer se sostiene sobre cuatro pilares íntimamente relacionados entre sí: El reconocimiento de la ambigüedad y ambivalencia de la vida; el desmarque de todo acceso al misterio de Dios con el único auxilio de las fuerzas humanas; la constatación de que el mundo ha entrado en un silencio religioso y la propuesta de un cristianismo adulto y arreligioso ${ }^{25}$.

Dietrich Bonhöeffer mantendrá que la revelación de Dios aparece en el cuerpo de Cristo bajo dos expresiones: Por una parte, en el cuerpo crucificado y resucitado y, por otra, en el Espíritu que forma un nuevo cuerpo: la Iglesia.

Cuerpo crucificado y resucitado: si partimos de la II carta de Pablo a los Corintios 5,19: "Porque en Cristo estaba Dios reconciliando al mundo consigo, no tomando en cuenta las transgresiones de los hombres, sino poniendo en nosotros la palabra de la reconciliación". Por eso aparecen la vida y la muerte del Señor como un gran misterio. Además, mantiene una meta significando, que solo Dios nos puede desvelar ante nuestros diminutos ojos. La vida va más allá de la muerte y la muerte queda envuelta en la vida. La cruz nos manifiesta la confrontación de Dios con el mundo. La cruz nos desvela la historia de la violencia del hombre y la gravedad del pecado del mundo. Dios se enfrenta a la violencia desatada por el hombre y se mide por la misericordia violentada en la cruz a manos de los hombres y por sus pecados, pero superada definitivamente por la acción de la misericordia divina, pues la muerte de Jesús en la Cruz, donde puede parecer la derrota de Dios, se alza por el contrario la Vida plena por el Espíritu, en Dios que sigue salvando al hombre. La debilidad de Dios va decantándose progresivamente hasta una situación que podemos denominar límite, pues llega a su total desprendimiento, cuando los hombres, dominados por el pecado, tratan de buscar y arrebatar a lo más querido: la Palabra, el Hijo de Dios, el unigénito. Así Dios queda enajenado y debilitado. El Padre entrega a su Hijo para la salvación. Para Dietrich Bonhöeffer lo esencial es preguntarse por Jesucristo ${ }^{26}$. Pero esta pregunta a la que

\footnotetext{
${ }^{24}$ Cf. D. BonhöEfFER, Resistencia y sumisión. Cartas y apuntes desde el cautiverio, Salamanca 1983, 20.

${ }^{25}$ Cf. E. Bueno DE LA Fuente, Dietrich Bonhöeffer. La fe adulta y comprometida, en Aula de Teología. Ciclo II: teólogos clásicos del siglo XX, Santander 27-01-2009, 2.

${ }^{26}$ Cf. D. BonHöEFFER, Quién es y quién fue Jesucristo, Barcelona 1971, 30-46.
} 
conlleva una respuesta supone no darla solo de la razón sino también desde el asentimiento, desde la existencia. La teología bascula permanentemente entre encarnación, vida, pasión, muerte y resurrección del Señor Jesús.

No se puede entender a Jesucristo solamente desde los planteamientos dogmáticos de la teología ni metafísicos de la filosofía. Dietrich intenta siempre presentarlo desde la opción personal, desde la relación con Él, que debe su sentido a la Palabra de Dios. Su Cristología, tiene sentido desde la realidad de la Palabra encarnada, hecha hombre. Para él, el significado salvífico, debe entrelazar no solo en la muerte acaecida, sino la vida, el mensaje de la llegada del Reino, su anuncio, los signos que dan sentido a su muerte y, desde ella, se afirma la entrega, la rotundidad de la vida, su claridad y el sentido definitivo: la redención. Pues así manifiesta claramente que la cruz es manantial inagotable de amor, de justicia, de perdón, de caridad, de compromiso, de donación, de servicio, de generosidad. Su existencia es, sin duda, sinónimo de la radicalidad entregada y ofrecida por la salvación de los hombres. Otro de sus puntos, a veces controvertidos, es que en la desolación de la cruz aparece el silencio de Dios. En Mc. 15,34 aparece la expresión: “Dios mío, Dios mío, por qué me has abandonado". Lo único que aquí se puede oír nítidamente es ese silencio. Aparece la inoperancia, la impotencia y la indiferencia aparente de Dios. Pero Dios se manifiesta con toda profundidad en el misterio de la muerte de Jesús, que se transforma en su liberación, la muerte va aparejada a la resurrección. Porque es poder del Espíritu Santo en la Resurrección el que da sentido y vida. El sentido de la debilidad de Dios ante el hecho de la crucifixión del Hijo, manifiesta la cercanía al hombre en su sufrimiento personal: la realidad existencial ha de vivirse desde la cruz y la resurrección ${ }^{27}$; desde el pensamiento de Dietrich recoge: "Lo único que nos permite ser como él fue, es que él fue como nosotros somos. Ahora, en la sencillez del seguimiento, vivimos una vida semejante a la de Cristo"28.

El Espíritu que forma un nuevo cuerpo: la Iglesia.

La Iglesia desde el seguimiento se juega toda su credibilidad. Había afirmado anteriormente la importancia de la palabra y Bonhöeffer afirma: "Si hay algo en Cristo que reclama toda mi vida con la plena seriedad de

${ }^{27}$ Cf. J. Moltmann, El Dios crucificado, Salamanca 1977, 269-270.

${ }^{28}$ Cf. D. BonhöEFFER, El precio de la gracia. El seguimiento, Salamanca 1986, 215. 
que es Dios mismo quien habla, y si la palabra de Dios se hizo presente una vez y solo en Cristo, entonces Él no tiene una importancia relativa para mí, sino que esa relevancia es absoluta y urgente... Entender a Cristo significa tomarle en serio. Comprender su afirmación es aceptar con total seriedad su absoluta reclamación de nuestro compromiso" ${ }^{29}$. La teología que avanza y reflexiona sobre cómo es Dios, es decir, experto en gloriarse en lo débil y despreciable del mundo, puesto que Dios se manifiesta claramente en la sencillez, en la humildad, en lo escondido, en lo recóndito. La comunidad creyente, la Iglesia es lugar favorito de Dios.

Bonhöeffer está considerado, a todos los efectos, como un mártir que se opuso a la maldad, desde la fe, el coraje y la valentía. Porque en la Encarnación se nos revela cómo el amor a Dios y el amor a los hombres están indisolublemente unidos. Él experimenta en su propia existencia que el seguimiento de Jesús significaba pagar un alto tributo. También su apertura recuerda que Bonhöeffer ha sido una figura de gran importancia de la cual se han enriquecido de su acción y de su obra cristianos más allá de todas las fronteras confesionales ${ }^{30}$. Dietrich comparte la visión que "el cristianismo predica el valor infinito de aquello que en apariencia no vale nada, y la infinita falta de valor de aquello que parece tener todo el valor"31. Hoy en día, mantenía él, ni se le escucha ni se muestra demasiado interés por la Iglesia. Algo de lo que actualmente también ocurre. Además, añade que la proclamación de la Buena Nueva supone una pesada carga sobre los creyentes, sobre cada hombro. La relación con Dios no se realiza desde la entidad religiosa, más bien, es una nueva vivencia, en la medida que estamos vinculados en la existencia para los demás, participando en el ser de Jesús. Ante el conflicto existente en la sociedad alemana de los años 30 del siglo XX, cabía hacerse la pregunta fundamental: ¿Qué es y qué hace la Iglesia si solo se preocupa de sus propios fieles, y no se inmuta ante la vejación de los otros? Debe de defender su propio espacio, su propia existencia cuando lucha por su causa y la causa de los demás. Cuando

${ }^{29}$ Cf. E. MetaXas, Bonhöeffer: Pastor, Mártir, Profeta, Espía, Nashville (Tennessee) 2012, 82-83.

${ }^{30}$ Cf. J. J. Alemany, Resistencia o sumisión. El testimonio de Dietrich Bonhöeffer, Santiago de Chile 1988, 8.

${ }^{31}$ Cf. E. Metaxas, Bonhöeffer: Pastor, Mártir, Profeta, Espía, Nashville (Tennessee) 2012,85 . 
no lo practica, entonces pasa a ser una mera sociedad sin más, aunque parezca religiosa. La Iglesia ha de ser la Iglesia de Dios en el mundo. En esto consiste el seguimiento de Jesús, en aprender a creer. Su eclesiología es radicalmente eclesiológica. Sin duda, uno de los grandes planteamientos desde la teología, y particularmente desde la eclesiología, sería que la Iglesia, más que una expresión esencial e invisible, es una nueva adecuación a su manifestación y expresión en el mundo y esto ha constatarse, puesto que, en su propia naturaleza, aparece como la manifestación de Jesucristo en forma de comunidad gracias a la acción del Espíritu Santo. Esto es lo que él, denomina como la corporeidad histórica de la Iglesia, para que en ella tome cuerpo la acción de Jesucristo. Para esto recupera la idea de Mt. 5,14: "Vosotros sois la luz del mundo. No puede ocultarse una ciudad situada en la cima del monte". La Iglesia tiene la responsabilidad de hacer presente a Cristo en la historia. Una historia que, además de ser universal, también lo es a nivel personal ${ }^{32}$.

Respecto a la llamada segunda época: Distingue entre fe cristiana y actitud religiosa. Aborda los grandes temas humanos como son el dolor, el sufrimiento y la muerte. Su importancia radica no solo por los temas afrontados, sino porque resulta ser un signo permanente de una teología que se encarna en una existencia concreta que desembocará, por distintos motivos en la muerte. Siempre miró a Jesucristo e intentó orientar su mirada hacia el Señor que nos ha regalado a su Iglesia. Nuestra vinculación con Cristo fue para Dietrich, el único sostenimiento a lo largo de su existencia. Para él, todo había sido regalo, su propia vida y la vida misma. Toda su visión teológica gira sobre la ética y el compromiso político. Son los tiempos de los escritos desde la cárcel. Sus disertaciones se plantean desde el plano de su teología: es la crítica política con todas las consecuencias. Su argumento el de la Encarnación del Verbo. En ella aparece en todo su esplendor la revelación de Dios que es amor y un amor dirigido a los hombres y están estrechamente unidos. De ahí surge la fraternidad humana que es el único camino a la praxis, donde se reconoce la dignidad humana. La dignidad del hombre no proviene de ningún tipo de derecho, sino por

${ }^{32} \mathrm{Cf}$. http://www.lupaprotestante.com/blog/dietrich-bonhoeffer-el-compromiso-deuna-fe-disidente/ Visto 04-04-2020 Cf. EduARdo Delás SEgura, Dietrich Bonhöeffer un teólogo a contratiempo, Tarragona $2012^{3}$. 
ser hijo de Dios. Por eso sería inaceptable la exclusión, la negación y la opresión del prójimo ni tampoco el poder atentar a sus libertades ${ }^{33}$. Otra cuestión diversa es que el pecado y el mal a los que el hombre tiene una clara propensión a veces sean conculcados. Como teólogo luterano advertía no existen teorías adecuadas y determinadas a la hora de enfrentarse a situaciones límite como era la muerte intempestiva de seres humanos, por el mero hecho de ser de otra etnia o religión, que fueron masacrados de manera tan inmisericorde. Entre la sumisión a la autoridad constituida y la exigencia de un culto idolátrico, el cristiano debía optar, pues la única sumisión es a la ley de Dios y se aplicaba el texto de Hch. 4,19 donde se dice: "Juzgar si es justo delante de Dios obedeceros a vosotros más que a Dios", si se está pidiendo la vida, pues está claro que la vida no es de la autoridad sino de Dios mismo. Bonhöeffer clarifica que es "la fe la que contribuye realmente a consolidar y salvaguardar la propia existencia del ser humano, ayudando a este a elevarse sobre el nivel de la existencia meramente animal. Tomando la humanidad como existe hoy, y tomando en consideración el hecho de las creencias religiosas que generalmente se mantienen y que han sido consolidadas a través de nuestra educación, puesto que sirven como bases morales en la praxis, si aboliésemos ahora la enseñanza religiosa y no la reemplazásemos por algo de igual valor, el resultado sería que los fundamentos de la existencia se verían seriamente sacudidos. Podemos decir que el hombre no vive meramente para servir a los altos ideales, sino que estos ideales, a su vez, proporcionan las condiciones necesarias de su existencia como ser humano. Y así el círculo se cierra" ${ }^{34}$. Estas circunstancias darán lugar a una fuerte tensión en su conciencia, al ver sacudidas sus creencias por el abominable régimen nacionalsocialista ${ }^{35}$. Es muy duro al establecer la prevalencia de su fe cristiana ante una sociedad que ha perdido el norte. En ese momento Alemania se encontraba en una profunda desorientación social, moral y política. La

${ }^{33} \mathrm{Cf}$.http://www.lupaprotestante.com/blog/dietrich-bonhoeffer-el-compromiso-deuna-fe-disidente/ Visto 04-04-2020 Cf. Eduardo Delás SEgura, Dietrich Bonhöeffer un teólogo a contratiempo, Tarragona $2012^{3}$.

${ }^{34}$ Cf. J. I. GonZÁlez FAus, Idolatrías de Occidente, Barcelona 2004, 13.

${ }^{35} \mathrm{La}$ llegada al poder de Hitler y su política basada en la supremacía de la raza aria y la persecución y matanza de los judíos, precipitará los acontecimientos, de tal modo que la resistencia pacífica llegará a sus límites. 
idea del nuevo hombre propuesto por el sistema represor del régimen, se introdujo en la sociedad, por falta de valores, y ante una población ávida de orgullo y de estima y unos medios de comunicación sectarios y perniciosos que doblegaban a la opinión pública alemana. La Iglesia luterana en Alemania se dividiós ${ }^{36}$.

\section{Dietrich Bonhöeffer: miembro de la Iglesia Confesante}

Se trata de un aspecto muy importante en su trayectoria de hombre de probada y profunda fe. Esto traerá sus consecuencias. Dada la explosiva situación religiosa y socio-política había provocado una toma de postura ya desde el año 1934 con la creación de la Iglesia Confesante, de la que tanto Karl Barth como Dietrich Bonhöeffer fueron miembros fundadores. Esto sucede ante la división de las Iglesias en Alemania: por un lado, los Cristianos Alemanes que conformaban la creación de una Iglesia de Reich como resultado final de la fusión de una serie de Iglesias territoriales alemanas; el marcado carácter popular que será expresión de todas las fuerzas religiosas de Alemania, es decir un sincretismo religioso; aceptación e implantación del principio del caudillaje, para llegar al racismo y al antisemitismo asumiendo las leyes arias. En las elecciones realizadas en julio de 1933 le dio la abrumadora mayoría. Eso supuso una escisión por parte de las Iglesias: el proceso de disgregación eclesial, dentro del movimiento de los Cristianos Alemanes, incapaces de administrar y liderar el proceso y, por otro lado, al mismo tiempo, se lleva a cabo el proceso de concentración de fuerzas renovadoras, en torno a la Federación de emergencia de pastores de Niemöller, de los Sínodos libres y de las Comunidades confesantes. Frente a la corriente de los Cristianos Alemanes aparece la Iglesia Confesante con el lema de que "la Iglesia sea Iglesia" 37 . La reunión de los 139 representantes de la Iglesia Luterana y la Iglesia Reformada, se unieron bajo una sola confesión de un solo Señor de la Iglesia una, santa y apostólica.

\footnotetext{
${ }^{36}$ Cf. H. VAll, Iglesia e ideología nazi. El sínodo de Barmen 1934, Salamanca 1976, 40-58.

${ }^{37}$ Cf. H. VAll, Iglesia e ideología nazi. El sínodo de Barmen 1934, Salamanca 1976, $13-16$.
} 
Por tanto, en vista de los errores de los Cristianos Alemanes y del actual gobierno de la iglesia del Reich que devastan la misma iglesia y hacen saltar la unidad de la Iglesia Evangélica Alemana, confesamos, según el Sínodo de Barmen, donde se determinan bajo una Declaración, las siguientes verdades evangélicas. En el artículo primero se confiesa: "Jesucristo, tal como es testificado en las Escrituras, es la única palabra que tenemos que escuchar, en la que tenemos que confiar y a la que tenemos que prestar obediencia en la vida y en la muerte, debemos confiar y obedecer" ${ }^{\prime 3}$. La intención de la Iglesia Confesante no es crear una división con la creación de otra iglesia nueva, sino tratar de resistir desde la fe y la unidad a las fuertes presiones a que estaban sometidos por los Cristianos Alemanes como iglesia estatal al servicio del nacionalsocialismo, bajo los ejes de la persecución y la dilación para silenciar la corrupción de un sistema que había embarcado al pueblo alemán a una guerra sin cuartel y, además, perdida de antemano por los desvaríos de una clase política obscena y corrupta, con la pretensión pública de conseguir una amplia renovación moral. ¿Dónde se encontraba esa ética tan escenificada por el régimen? ¿Qué sacó de provecho el pueblo alemán de esa inexistencia de una mínima moralidad pública? ¿Le quedaba alguna salida viable a Dietrich Bonhöeffer en esta situación de corrupción desde su compromiso de cristiano perteneciente a la Iglesia Confesante o Iglesia de la Confesión? $\mathrm{Su}$ compromiso con la fe, desde la intimidad de su corazón, no le dejaba tranquilo si no actuaba, en nombre de esos principios cristianos ${ }^{39}$. Su entrega al servicio de la fe en Jesucristo le llevará por caminos inciertos para su seguridad, pues cada día que pasaba, se veía mucho más controlado por la policía política de la Gestapo y sus pasos están muy vigilados ${ }^{40}$. Tuvo que salir de la universidad, dejar de dictar conferencias e incluso de publicar, todo de forma estricta. Bonhöeffer tenía muy claro que la Iglesia estaba obligada a combatir la injusticia política.

\footnotetext{
340-341.

${ }^{39}$ Cf. G. Hourdin, Dietrich Bonhöeffer: víctima y vencedor de Hitler, Bilbao 1995.

${ }^{40} \mathrm{Cf}$. Ch. Feldmann, Tendríamos que haber gritado. La vida de Dietrich Bonhöeffer, Bilbao 2008.
}

${ }^{38}$ Cf. H. VAll, Iglesia e ideología nazi. El sínodo de Barmen 1934, Salamanca 1976, 


\section{Dietrich Bonhöeffer: ciudadano comprometido}

Ante los planteamientos amorales del régimen nacionalsocialista que pretendían imponer a la sociedad alemana la soflama de un Führer, un pueblo, un Reich, Dietrich Bonhöeffer plantea un solo Señor, una sola fe, un solo bautismo. Trata de establecer desde la vivencia personal, la superación de la realidad en la que se encuentra inmerso y se postula con el compromiso del cristiano, de la Iglesia Confesante, para proveer con todas las fuerzas a la Iglesia ante el momento histórico que se avecina ${ }^{41}$. Los sucesos se irán precipitando progresivamente y los acontecimientos desbordarán muchos planes que se habían propuesto con anterioridad. Decide todavía un mayor compromiso de vida y es anunciar que el crucificado, ya maltratado con juicios injustos y en el camino hacia el calvario con la cruz, es, además, humillado y coronado con espinas, que proclama desde el madero de la cruz que él mismo es la verdad, el Hijo de Dios: Que mayor autenticidad de vida, que pagará más adelante con su vida. Uno de los primeros compromisos de Bonhöeffer, es, sin duda, el ecuménico ${ }^{42}$. Enseguida se da cuenta de los conflictos que pueden aparecer entre las Iglesias, si siguen desunidas, pues el maligno va a irrumpir con todas sus fuerzas para destruirlas. Su lema es esencial a la vivencia cristiana: Soy hermano de otra persona gracias a lo que Jesucristo hizo por mí y me hizo a mí; la otra persona se ha vuelto un hermano para mí gracias a lo que Jesucristo hizo por él. Entra de lleno en diferentes organizaciones ecuménicas. Trata de organizarlas, se presta a dictar numerosas conferencias y anuncia desde el púlpito de la palabra a un mayor compromiso de fe y de vida de los fieles cristianos: explicará y también disertará en cuestiones tan conflictivas como la política, la economía, la sociedad, la ética y la moral, la paz internacional y criticará ampliamente los dos grandes movimientos en contra del hombre como son el nacionalsocialismo y el marxismo. Esto le determina y pasará a estar muy vigilado.

Destaca en una serie de sociedades, entre ellas, llega a ser secretario general de juventudes de la Federación Luterana Mundial. Con su parti-

\footnotetext{
${ }^{41}$ Cf. G. Hourdin, Bonhöeffer. Una Iglesia para mañana, Madrid 1972.

${ }^{42}$ Cf. G. Hourdin, Dietrich Bonhöeffer: víctima y vencedor de Hitler, Bilbao 1995,
} 15. 
cipación profundiza en el movimiento de Vida y Acción ${ }^{43}$ especialmente y, en Fe y Constitución, en mucha menor medida. Ante las circunstancias que vive el país, su participación es mucho menor en organizaciones como la Asociación Cristiana de Jóvenes y la Asociación Alemana de Jóvenes. ¿Qué le ha llevado a tal compromiso? La reflexión profunda de su vivencia del cristianismo, de su fe inquebrantable en Jesucristo ${ }^{44}$. Tiene muy asumido el sentido de la Trinidad. Dios Padre nos dio en Jesús a aquel que murió por todos. Vivió Cristo nuestra vida y murió nuestra muerte. Aceptado su sacrificio y elevado a una nueva vida junto al Padre, bueno será que por él nos conceda también a nosotros, que hemos muerto con él, poder hacernos uno por el Espíritu Santo, y vivir ahora y por siempre en la abundancia de su divina presencia, o sea en unidad de comunión. Mayor compromiso del sentido ecuménico no se puede expresar mejor. Todo ello le va a llevar a prodigarse por todo el mundo: Berlín, Londres, Cambrige, Epsom, Barcelona, Nueva York, Zurich, Basilea, Ginebra Lausana, Edimburgo, Estocolmo, etc. Se trata de un hombre conocido y reconocido a todos los efectos. La actividad ecuménica en Alemania es totalmente sospechosa siempre. Desde una teología dialéctica, la influencia teológica de Dietrich Bonhöeffer en la teología ecuménica ${ }^{45}$ es evidente. Se trata de una lucha contra el Estado, que quiere dominar a las diversas Iglesias alemanas.

\section{Dietrich Bonhöeffer: ciudadano perseguido}

Será otra de sus características. Hombre libre pero perseguido por sus ideas y sus acciones. Las actividades ilegales dentro del marco pseudojurídico de la Alemania nazi le hacían estar siempre sobre la cuerda floja. La Iglesia Confesante, también conocida como Iglesia de la Confesión fue un movimiento de las iglesias cristianas protestantes fundado en Alemania en 1934 cuya finalidad era oponerse al intento de control nazi de las distintas iglesias alemanas. Conocedor de la Sagrada Escritura fue, ante todo,

\footnotetext{
${ }^{43}$ Cf. H. VAll, A la búsqueda de una nueva sociedad, Madrid 1997, 13-20.

${ }^{44}$ Cf. R. MARLÉ, Dietrich Bonhöeffer. Testigo de Jesucristo entre sus hermanos, Bilbao 1970.

${ }^{45}$ Cf. A. Dumas, Una teología de la realidad: Dietrich Bonhöeffer, Bilbao 1970.
} 
un hombre íntegro y cabal que fue asumiendo en su vida las verdades del Evangelio y ello comportó recoger en coherencia los postulados de la Iglesia Confesante y oponerse a todas las atrocidades respecto a los judíos y demás personas que por ley se les denigraba, se les confiscaba y se les deportaba a centros de trabajo forzados y campos de concentración, seudónimo de terror, odio y muerte. Su oposición a los Cristianos Alemanes: Iglesia nacional alemana compuesta por luteranos, calvinistas, presbiterianos, congregacionistas y metodistas supuso grandes desafíos. Sabía a qué se enfrentaba y lo hizo conscientemente para ayudar a la Patria después de la guerra.

Sus actividades dejaban un rastro muy proclive para que pudiesen existir denuncias y delaciones fáciles. Se convierte fácilmente en un líder de oposición al nazismo preminente. Escribe que "no es posible fijar en el terreno de los principios el límite entre resistencia y sumisión, pero ambas han de coexistir y ser practicadas con igual decisión. La fe nos exige esta actitud flexible y viva. Solo de esta manera lograremos soportar y hacer fecundas cuantas situaciones se nos presenten" ${ }^{46}$. Por eso trabaja y se hace cargo del Seminario clandestino de Finkenwalde que pertenece a la llamada Iglesia Confesante hasta que es clausurado por la autoridad gubernativa en 1937. En su proceso de vida, Dietrich pasa de estar situado en su resistencia pasiva a otra totalmente activa. Así clarifica que: "se integró decididamente en aquella fórmula de resistencia cuando había necesidad de hombres y después de haber estudiado, como teólogo, todas las otras normas de escapar al dilema que se le planteaba. En el momento en que en nombre de los esclavos la tiranía dominaba la vida del prójimo cargando culpas sobre sus nombres, y una vez que sus métodos se impusieron en toda la amplitud del Reich, sonó también para Bonhöeffer la hora, de exigencias morales, de la conspiración" ${ }^{47}$.

Su vida la ve claramente a través del signo de la cruz, como buen luterano, teología del calvario asumida por la theología crucis, donde profundiza sobre el tema: “Cristo, Hijo de Dios, fue condenado a la crucifixión como cualquier bandido de derecho común. Bonhöeffer también será col-

\footnotetext{
${ }^{46}$ Cf. D. BonhöEFFER, Resistencia y sumisión, Salamanca 1983, 158.

${ }^{47}$ Cf. E. BETHge, Dietrich Bonhöeffer, teólogo, cristiano, hombre actual, Bilbao 1970,
} 973. 
gado, como cualquier malhechor"48. Su exigencia como ciudadano lo marca siempre su compromiso que le llevará a posicionarse en contra del régimen, pero de manera astuta. A partir del año 1939, entra a formar parte de un grupo clandestino de resistencia, encabezado por el almirante Canaris, que se proponía derrocar el nacionalsocialismo. Más tarde, es arrestado en abril de 1943, procesado por alta traición y encarcelado en la prisión de Tegel en Berlín. Su gracia cara está recogida y vivida por él, en estos acontecimientos: "La gracia barata es la gracia sin seguimiento de Cristo, la gracia sin cruz... la gracia es cara porque le ha costado cara a Dios, porque le ha costado la vida de su Hijo, y porque lo que le ha costado caro a Dios no puede resultarnos barato a nosotros" ${ }^{49}$. Por eso la conversión ha de ser auténtica.

La fe cristiana debe ser portadora de una visión abierta, dinámica, alternativa, profética y que, además, sea crítica con la sociedad y la situación política. Ello debe poder contribuir a establecer las bases de una sociedad comprometida y responsable. La fe debe relacionarse con la historia. $\mathrm{La}$ fe aparece en la historia, historia general, pero también en la historia de la salvación. Igualmente se ha de relacionar la creación y la escatología, pero en ambos casos es necesario la investigación y la reflexión teológica. Resulta muy difícil la interacción entre Evangelio e ideologías. Es Cristo quien permanece por encima de todo ello $^{50}$. Las dificultades aparecen dentro del seno de las propias filas de la Iglesia Confesante, en el Seminario Finkenwalde, antes de su clausura por la persecución ladina a los seminaristas, por parte de las fuerzas de la policía política. Otros conflictos que tiene que vivir Dietrich Bonhöeffer son los derivados de los problemas representativos en el movimiento ecuménico, pues siempre pretendió que, la Iglesia Confesante, fuese la única representante de las Iglesias alemanas ante dicho movimiento, frente a la de los Cristianos Alemanes, supeditados al régimen. La actitud intransigente será un tanto incómoda para ese desarrollo del ecumenismo y será causa de enfrentamientos internos por pasar a ser oficialmente sospechosos.

\footnotetext{
114-115.

${ }^{49}$ Cf. D. BonHöEFFER, El precio de la gracia. El seguimiento, Salamanca 1986, 15-16.

${ }^{50}$ Cf. H. VAll, Iglesia e ideología nazi. El sínodo de Barmen 1934, Salamanca 1976, 310-311.
}

${ }^{48}$ Cf. G. Hourdin, Dietrich Bonhöeffer: víctima y vencedor de Hitler, Bilbao 1995, 
Después del regreso precipitado de Nueva York, del cual discrepan sus amigos americanos, en 1939, Dietrich Bonhöeffer, se tiene que enfrentar con la desgraciada realidad y también consigo mismo. Necesita plasmar su compromiso social, a pesar de las grandes dificultades a las que se va a enfrentar y piensa: "No tendré ningún derecho a participar en el restablecimiento de la vida cristiana en Alemania después de la guerra, si no comparto ahora las pruebas de esta época con mi pueblo". Incluso "los cristianos de Alemania estamos enfrentados a la terrible alternativa de, o consentir la derrota de nuestra nación, o consentir su victoria y, con ella, la destrucción de nuestra civilización. Sé por cuál de estas dos alternativas tengo que decidirme, pero no podré tomar esta decisión mientras me encuentre en un lugar seguro" ${ }^{51}$.

De aquí saldrán los momentos más conflictivos, puesto que asumiendo los retos a que se enfrentará por el deber de conciencia y el compromiso cristiano que posee y, al mismo tiempo, es una etapa trepidante en un clima de tensión permanente y que le empujará a tomar decisiones vitales. Pero nunca renunció a ellas, por comprometidas que fuesen. Estudió, investigó, averiguó, aceptó, confirmo, todo lo que creía para ponerlo en práctica, a pesar de lo que le podía traer consigo, especialmente para su vida personal. No ahorró ni escatimó para disimular sus opciones. Lo vivía con total tranquilidad y prueba de ello es que siguió escribiendo y pensando en el futuro, especialmente el futuro para que después que finalizase la guerra, pudiera participar en profundidad en el nuevo tiempo de paz, uno de los argumentos para el ecumenismo entre las Iglesias cristianas: la paz internacional. Ayudó al traslado de muchos judíos a Suiza donde residía Karl Bart. Ejerció el espionaje. Sirvió como doble agente, desde su posición en Munich ${ }^{52}$. La oposición al régimen, si se era descubierto, pesaba sobre tal persona la detención y la muerte, bien lentamente en cualquier prisión de la Gestapo, o bien de la manera más cruel en un campo de exterminio, ideado por el sistema nacionalsocialista para aplicar a los disidentes, presos políticos, o de otras etnias como judíos y gitanos, aplicándose también a los homosexuales. A través de sus contactos ecuménicos y a sus viajes, intentó establecer las posibilidades y las condiciones

${ }^{51}$ Cf. CH. Feldmann, Tendríamos que haber gritado, Bilbao 2007, 142.

${ }^{52}$ Cf. G. Hourdin, Bonhöeffer. Una Iglesia para mañana, Madrid 1972, 36-37. 
para la paz con los Aliados. En prisión oye, trata de escuchar, dialoga, habla y consuela a otros prisioneros de distinta condición y opinión.

\section{Dietrich Bonhöeffer: pastor detenido y asesinado}

Finalmente fue detenido el 5 de abril de 1943. Hay que tener en cuenta que, tanto el comportamiento como sus decisiones poseen un tono altruista, manifiestan la necesidad permanente de resistir siempre contra toda iniquidad, de ayudar a desanclar todo tipo de injusticias y de buscar nuevos itinerarios hacia el futuro, que ha de ser especialmente mucho más humano. Su oposición era aquella que pretendía, ante todo, salvaguardar la ley y la fe religiosa, algo fuera de lo común. De alguna manera se lo había ganado a pulso.

Aproximadamente Dietrich estuvo durante un año y medio en la prisión de Tegel en espera de juicio. Durante este tiempo desarrolló toda su capacidad intelectual escribiendo, haciéndose querer por compañeros y guardias. No se debe olvidar de dónde venía, una familia aristocrática y con una economía desahogada. Además, llegaba del servicio de contraespionaje alemán, no se trataba de un prisionero más. Incluso se pensó en alguna fuga bien preparada, pero al final desistió por miedo a las posibles represalias en el orden familiar. Fracasado del plan para matar a Hitler el 20 de julio y el descubrimiento en septiembre de 1944 de la implicación de la Abwehr, por medio de documentos secretos relacionados con la conspiración, Bonhöeffer fue acusado de asociación con los conspiradores. Ante este cambio de status, fue trasladado de la prisión militar de Tegel en Berlín, a los calabozos de detención en la prisión de la sede de la Seguridad del Reich, prisión de alta seguridad de la policía política, donde será torturado. El 7 de febrero de 1945, fue trasladado al campo de concentración de Buchenwald ${ }^{53}$, donde aparece el silencio de manera más densa, y finalmente el 3 de abril al campo de concentración de Flossenbürg. Será cuando se encuentra en la soledad de la prisión donde el filósofo, el teólogo, el poeta, el místico, el hombre, se da cuenta de la ausencia total de Dios en la conciencia de los hombres. Su visión de las relaciones entre la fe y el mundo resulta trastornada. En sus cartas, Bonhöeffer dice

\footnotetext{
${ }^{53}$ Cf. G. Hourdin, Bonhöeffer. Una Iglesia para mañana, Madrid 1972, 51.
} 
que el lenguaje religioso de los detenidos que están con él, le causa hasta malestar. Se introduce en el lenguaje humano, secular, incluso para hablarles de Cristo $^{54}$ y de Dios ${ }^{55}$. Para Bonhöeffer, Dios siempre fue una realidad muy cercana. Sin acusación y sin proceso fue condenado a muerte, Bonhöeffer fue despojado de su ropa, torturado y ridiculizado por los guardias, y llevado desnudo al patíbulo en la madrugada del 9 de abril de 1945, siendo testimonio vivo ${ }^{56}$. Bonhöeffer, como profeta, presiente que las generaciones futuras tendrán que hablar de Dios, pero sin religión. Ya en su tiempo se planteaba: ¿Cómo ser creyente en una sociedad que ya no tiene necesidad de Dios? Y, además, ¿qué puede hacer la Iglesia en el mundo ${ }^{57}$, para llegar en definitiva a la gran pregunta: ¿Quién es Cristo hoy? ${ }^{58}$ Muchas son las dificultades a las que se debe enfrentar el hombre. Un hombre desolado en medio de los campos de concentración. Dios no nos olvida, pues somos sus hijos muy amados, a la vez únicos e irremplazables. Dios estaba en medio de esos campos, Pues Cristo seguía crucificado en la cruz, a la vista de todos, gentiles y paganos; judíos y griegos; hombres y mujeres, pero era necesario reconocerlo, allí entre los barracones y los crematorios. El origen del problema del mal, no está en Dios, sino en el hombre (Gn. 2 y 3). El sufrimiento es en último término, consecuencia de la injusticia del hombre, pero nunca de Dios.

\section{Dietrich Bonhöeffer: noticia del fallecimiento}

Uno de los grandes personajes, conocido por su amistad con Dietrich Bonhöeffer, fue el pastor luterano Martin Niemöller, que es recordado por un sermón de 1946, después existen distintas versiones desde 1955 y siguientes y que, además, es falsamente atribuido al dramaturgo Bertolt Brecht, debería servir de recordatorio ante una sociedad adormecida que

${ }^{53}$ Cf. G. Hourdin, Bonhöeffer. Una Iglesia para mañana, Madrid 1972, 51.

${ }^{54}$ Cf. D. BonhöEFFER, Quién es y quién fue Jesucristo, Barcelona 1971, 25-30.

${ }_{55}$ Cf. G. Hourdin, Bonhöeffer. Una Iglesia para mañana, Madrid 1972, 88-91.

${ }^{56}$ Cf. M. MANResA, Recuperem els testimonia. Dietrich Bonhöeffer als quaranta anys de la sera execució nazis, Barcelona 1985.

${ }^{57}$ Cf. G. Hourdin, Bonhöeffer. Una Iglesia para mañana, Madrid 1972.

${ }^{58}$ Cf. D. BonhöEFFER, Quién es y quién fue Jesucristo, Barcelona 1971, 40-46. 
se ha hecho indiferente frente a los enemigos de Dios y de la libertad, incluso en estos tiempos que corremos. Dice así:

Cuando los nazis vinieron a llevarse a los comunistas, guardé silencio,

porque yo no era comunista.

Cuando encarcelaron a los socialdemócratas, guardé silencio,

porque yo no era socialdemócrata.

Cuando vinieron a buscar a los sindicalistas, no protesté, porque yo no era sindicalista.

Cuando vinieron a llevarse a los judíos, no protesté, porque yo no era judío.

Cuando vinieron a buscarme, no había nadie más que pudiera protestar.

Solo desde la experiencia de los campos de concentración, Dietrich Bonhöeffer expresará que solo un Dios que sufre puede ayudar ${ }^{59}$. La indiferencia constituye una puerta abierta al mal. Cada una de las Iglesias $^{60}$, defendió la situación desde diversos frentes. Las posturas fueron diversas, tanto desde el núcleo de los Cristianos Alemanes, como de la Iglesia Confesante y la Iglesia católica. Todas jugaron sus cartas, en un juego muy desigual. Toda la historia de estos años, supone la reflexión de una serie de planteamientos teológicos más específicos, donde la Iglesia manifiesta una tensión profética y crítica, en la medida en que es fiel a la Buena Noticia del Reino que predica y a la esencia de la propia verdad, es decir que Cristo es el Señor, pero no es solo Señor sino también juez de la Historia ${ }^{61}$. Posiblemente las condiciones de las comunicaciones al final de la guerra eran en Europa extremadamente difíciles y en los meses posteriores al conflicto no cambiaron demasiado. Se habían ido

${ }^{59}$ Cf. D. BonhöEFFER, Letters and Papers from Prison, London 1959, 122.

${ }^{60}$ Cf. J. M. García Pelegrín, La Iglesia y el nazismo: cristianos ante un movimiento neopagano, Madrid 2015.

${ }^{61}$ Cf. H. VALl, Iglesia e ideología nazi. El sínodo de Barmen 1934, Salamanca 1976, 21. 
liberando los campos de exterminio por parte de las tropas aliadas, tanto en el frente oriental como en el occidental. Los padres de Dietrich esperaban su vuelta en cualquier momento. En medio del caos reinante ante la descomposición del régimen, la familia Bonhöeffer permanecían sujetos al drama exterior por las escuchas de radio en lengua alemana de la BBC londinense. Una de las tardes, el 27 de julio de 1945, en una transmisión religiosa, tras el canto del himno de todos los santos, el comentarista anuncio: "Estamos aquí reunidos, en presencia de Dios, en memoria de su siervo Dietrich Bonhöeffer, que ofreció su vida en la fe y en la obediencia a su santa voluntad"62. De esta manera conoció la noticia la familia, sus padres Karl Ludwig y Paula, que fallecieron en 1948 y 1951, respectivamente.

\section{Dietrich Bonhöeffer: influyente en el pensamiento actual}

Si algo anuncia Cristo es ser el hombre para los demás y a la existencia cristiana como la participación por el compromiso en la misma huma$\operatorname{nidad}^{63}$. De todo se puede aportar. Los compromisos que fueron adquiridos durante su vida, resisten a todo tiempo, pues Dietrich Bonhöeffer, como hombre valeroso sigue siendo actual, su proyección del pensamiento se mantiene vivo y sigue repercutiendo su acción en muchas reflexiones posteriores del siglo XX e incide en el XXI. Esto ocurre porque su valor incalculable gira al estudio de su vida, de su obra y de su testimonio: vida, obra y testimonio conforman un trípode esencial para acercarse a Dietrich Bonhöeffer. Todo conforme a una figura que irradia la gratitud a la vida y el comportamiento basado en la ética. Es con Cristo con quien anda la Iglesia su propio camino en cada realidad, en la historia personal y en la historia del hombre. Además, Cristo vino en la pobreza, en la bajeza, en la mediocridad marginal, en el escándalo para nosotros. Así quiso Dios actuar cuando entró en nuestro mundo, desde el anonimato, la invisibilidad y la necesidad. De esta manera se anuncia al pueblo la salvación, en medio de la noche a unos, dormitando mientras cubrían el cuidado de los rebaños, y a otros en medio de la noche guiados por una estrella. La fe,

\footnotetext{
${ }^{62}$ Cf. G. Hourdin, Bonhöeffer. Una Iglesia para mañana, Madrid 1972, 9-10.

${ }^{63}$ Cf. D. BonhöEFFer, Resistencia y sumisión, Salamanca 1983, 266.
} 
sin duda, era la gran esperanza. En su teología se abunda el estudio de la figura de Jesús; hace una crítica sin piedad de la dimensión idolátrica del nacionalsocialismo; la responsabilidad moral y ética de los cristianos alemanes que respaldaron el régimen despótico de Hitler. Plantea en su reflexión teológica el famoso postulado: Etsi Deus non daretur: como si Dios no estuviera allí. Todo esto influirá en su percepción sobre la Iglesia, que es un reflejo de su situación personal. Es la fuente de la vivencia la experiencia personal. En esa reflexión aparece en primer término la Iglesia. Va descubriendo desde la experiencia vital a la Iglesia; después surge el ecumenismo, fruto del conocimiento que va obteniendo de sus viajes y de la necesidad que tienen todas de unirse bajo el mismo credo; posteriormente con el advenimiento del nacionalsocialismo y con la fuerza de su gran madurez aparecerá la imperiosa necesidad de la Iglesia Confesante, en oposición a una Iglesia dominada por el régimen como era la de los Cristianos Alemanes. Esto le creará muchos sinsabores y grandes recelos. Su trayectoria intelectual llegará a término con la incógnita de la Iglesia, una Iglesia peregrinante y en cautiverio. Por eso, la creación de esa Iglesia Confesante será decisiva, en su vida, en su pensamiento y en su existencia, juntamente unido en su creación a Martin Niemöller, Karl Barth y Gustav Heinemann.

Para Dietrich Bonhöeffer la auténtica trascendencia sucede en esa relación: el estar con los otros o para los otros. Cristo murió para compartir los dolores del mundo, para ser una presencia viva y esperanzadora en mitad del sufrimiento. Por eso desde la humildad y la obediencia se llega a Dios. Lo importante y trascendente es la entrega al prójimo, no el éxtasis místico que hace a Dios en el infinito inalcanzable. Dios nunca se sitúa fuera, sino que se encuentra en el centro de nuestro existir. En términos agustinianos Dios está en tu interior, en tu corazón: "Nos hiciste, Señor, para Ti y nuestro corazón está inquieto hasta que descanse en $T i^{\text {”"64 }} \mathrm{y}$, por supuesto, en aquella que dice: "Tú estabas más dentro de mí, que lo más interior que hay en mí mismo" "65. Lo que caracteriza al cristiano no es la obediencia a Dios todopoderoso, sino el amor al prójimo. Esto le llevaría a decir que matar es un mal objetivo, pero acabar con un tirano como

\footnotetext{
${ }^{64}$ Cf. San Agustín, Conf. I,1,1: PL 32, 661.

${ }^{65}$ Cf. San Agustín, Conf. III,6,11: PL 32, 687-688.
} 
Hitler es una aspiración legítima, pues en este caso prevalece el derecho a la vida de los pueblos deportados y exterminados.

Dietrich escribió el ensayo intitulado La Iglesia y la cuestión judía, en abril de 1933 en el que establecía claramente distintos niveles de responsabilidad de la Iglesia frente al Estado. Le retomaba en la categoría de status confessionis, planteando la difícil situación que debía afrontar la Iglesia luterana alemana condicionada por el régimen en su esencia y proclamación, tanto a los judíos bautizados en las diversas congregaciones luteranas como a la labor misionera entre los judíos ${ }^{66}$. El trabajo de Bonhöeffer sobre la cuestión judía consta de dos grandes partes: en primer lugar, el estudio del problema de la integración eclesiástica de los judíos cristianos; en este punto según él, el Estado no tiene nada que hacer; en segundo lugar, se plantea claramente el contrasentido teológico de una Iglesia "de hondas raíces alemanas" que excluye a ciertos miembros por motivos de raza o religión. En esta tesis dice: "No se trata en absoluto del problema de si los miembros de nuestra comunidad de origen alemán pueden admitir todavía la comunidad eclesial con los judíos. Más bien es misión de la proclamación cristiana decir: aquí, donde los judíos y los alemanes se unen bajo la palabra de Dios, está la Iglesia; es aquí donde se demuestra si la Iglesia sigue siendo o no Iglesia" ${ }^{67}$.

Todas estas leyes racistas eran, además, de discriminatorias, atacaban a un dato esencia de la Iglesia que es la Koinonia. De aquí la declaración de Barmen con Karl Barth y Bonhöeffer ${ }^{68}$. Ante estas circunstancias vendría la responsabilidad eclesial ante tales hechos. Estos quedaban claros bajo tres postulados: en primer lugar, la Iglesia tiene que plantear al Estado, hoy con toda claridad la acción estatal legítima en relación con la cuestión judía; en segundo lugar, la tarea la planteaba Bonhöeffer en el servicio a las víctimas de la acción estatal. Dice así: "La Iglesia tiene una obligación especial con las víctimas del orden social, aun cuando no pertenezcan a la comunidad cristiana"; en tercer lugar, se llega a los límites

${ }^{66}$ Cf. C. MÁrquez Beunza, Las Iglesias cristinas ante el apartheid en Sudáfrica. Un análisis teológico del documento Kairós, Madrid 2014, 214-215.

${ }^{67} \mathrm{Cf}$. https://nazismoyholocausto.blogspot.com/2009/05/dietrich-bonhoeffer-un-pastor-luterano.html Visto 11-04-2020.

${ }^{68}$ Cf. H. VAlL, Iglesia e ideología nazi. El sínodo de Barmen 1934, Salamanca 1976, $22-23$. 
más inauditos. Igualmente afirmaba: "si la Iglesia ve que el Estado ejerce demasiado o demasiado poco derecho y orden, está en la situación no solo de acoplar a las víctimas a la rueda, sino de lanzarse contra los mismos radios de la rueda". ¡Lanzarse contra los mismos radios de la rueda! Pero, ¿quién se lanzaría? ${ }^{69}$.

Bonhöeffer, echaría mano para encontrar una respuesta en la carta de san Pablo a los Romanos, en el capítulo 13,1-8. Pablo argumenta: Por tanto: "Sométanse todos a las autoridades constituidas, pues no hay autoridad que no provenga de Dios, y las que existen, por Dios, han sido constituidas. De modo que, quien se opone a la autoridad, se rebela contra el orden divino, y los rebeldes se atraerán sobre sí mismos la condenación". (Rom.13,1-2). De ahí que, Dietrich Bonhöeffer, exponga con todo su valor y su energía el argumento bíblico, según el cual la aceptación de la acción del Estado es su auténtica legitimación y no su capacidad de poder: supremacía de la autoritas sobre la potestas. Por eso advierte que la Iglesia tendrá siempre la obligación incondicional para con todas las víctimas de cualquier orden de la sociedad. La universalidad del pensamiento de Bonhöeffer trasciende el ámbito del creyente. Va más allá de lo que se ve o se intuye. Está presente y seguirá presente como toda forma de concientización del hombre, acerca de Dios, pues el hombre sigue pensando en la realidad transcendente de Dios y la presencia de la Iglesia de Jesucristo por medio de la acción del Espíritu Santo. Esto es así.

Bonhöeffer, se preguntaba sobre si Jesús si se negaba a enfrentarse al pecado del mundo o a su realidad: "Precisamente porque vivís en el mundo y el mundo es malo, tiene valor este principio: no debéis oponer resistencia al mal. Difícilmente podríamos reprochar a Jesús que no conoció el poder del mal, él, que desde el primer día de su vida se halló en lucha con el demonio. Jesús llama mal al mal y precisamente por eso habla de esta forma a los que le siguen"70. De esta manera, Bonhöeffer, enseña fehacientemente que solo la persona y la acción de Jesucristo nos enseñan el modelo para poder seguirle: "En la Iglesia no se trata de religión, sino de la figura de Cristo y de su configuración en una agrupación de hombres. Si nos aparta-

${ }^{69} \mathrm{Cf}$. https://nazismoyholocausto.blogspot.com/2009/05/dietrich-bonhoeffer-un-pastor-luterano.html Visto 11-04-2020.

${ }^{70}$ Cf. D. BonhöEfFer, El precio de la gracia. El seguimiento, Salamanca 1986, 99. 
mos de este punto de vista, aun cuando sea lo más mínimo, recaemos ineludiblemente en aquella programación de la configuración ética o religiosa del mundo de la que hemos partido. [...] Solo hay una configuración de y a esta figura de Jesucristo. El punto de partida de la ética cristiana es el cuerpo de Jesucristo, la figura de Cristo en la figura de la Iglesia, la configuración de la Iglesia de acuerdo con la figura de Cristo"71.

De otra parte, Bonhöeffer, nos plantea cuestiones vitales para el hombre: "La gran mascarada del mal ha trastornado todos los conceptos éticos. El hecho de que el mal aparezca bajo el aspecto de la luz, de la acción benéfica, de la necesidad histórica, de la justicia social, es sencillamente perturbador"72. De igual manera, Bonhöeffer, de nuevo insiste en el mandamiento desde la visión ética: "El mandamiento [de Dios] es la única capacitación para hablar desde el punto de vista ético. [...] el mandamiento de Dios es y sigue siendo siempre el mandamiento de Dios revelado en Jesucristo. No hay otro mandamiento de Dios, sino el que ha sido revelado por él y precisamente revelado de acuerdo con su beneplácito en Jesucristo"73. Más tarde, ahondará en el sentido crítico de la vida, de la existencia, de la fuerza impuesto mediante la violencia. Bonhöeffer, respecto a la crítica de la necedad referida al poder, aclara: "Para el bien, la necedad constituye un enemigo más poderoso que la maldad... frente a la necedad carecemos de toda defensa, el necio, a diferencia del malo, se siente enteramente satisfecho de sí mismo, e incluso puede hacerse peligroso cuando, levemente irritado pasa al ataque..." ${ }^{74}$. Fue una persona realmente comprometida con su entorno familiar, con la sociedad a la que perteneció y con el momento en el que tuvo que vivir y morir. Es un claro ejemplo de compromiso y de fe. La lucha contra el nazismo se enarbola cuando se da cuenta que no es posible mantener dos líderes: Jesucristo o la representación del maligno ${ }^{75}$. Esta lucha se mantuvo durante toda su vida intelectual que le llevó irremediablemente a la muerte. De igual modo la Iglesia católica tuvo que llevar adelante el enfrentamiento con el maligno, aunque

${ }^{71}$ Cf. D. BonhöefFer, Ética, Madrid 2000, 80-81.

72 Cf. D. BonhöefFer, Resistencia y sumisión, Salamanca 1983, 14.

${ }^{73}$ Cf. D. BonhöEfFer, Ética, Madrid 2000, 294 y 296.

${ }^{74}$ Cf. D. BonhöEfFer, Resistencia y sumisión, Salamanca 1983,16-17.

${ }^{75}$ Cf. A. Dumas, Una teología de la realidad: Dietrich Bonhöeffer, Bilbao 1970, 5960. 
ella había conseguido la ratificación de un concordato con la Alemania nacionalsocialista en 1933. El reconocimiento del sistema, se ahondó con dicha firma ratificada, entre Berlín y la Santa Sede, pero no sirvió prácticamente para nada y, además, relaciones diplomáticas se mantuvieron en el constante límite, de las protestas y las notas diplomáticas. La Iglesia católica en Alemania mantuvo el tipo, como obispo de Münster, Clemens August von Galen y Konrad von Preysing, obispo de Berlín, que desafiaron al régimen y denunciaron, día sí y otro también, todas las atrocidades cometidas contra disidentes políticos, judíos y disminuidos psíquicos. No todos los hicieron ${ }^{76}$.

Dietrich Bonhöeffer irá descubriendo a lo largo de su trayectoria personal el sentido de la unidad de la Iglesia. Es un punto central para la finalidad de la evangelización y de la acción profética. Es importante porque proporcionó una base teológica a todo el llamado movimiento ecuménico. Era un tiempo especial, con una hondura social y cultural, en medio de la historia que abrirá el servicio de la paz. La paz tan deseada por muchos y no alcanzada por nadie. En tales circunstancias vio con claridad que no existe más que una Iglesia para una sola realidad humana y esto supone dos temas: la responsabilidad de buscar la paz entre los países y la obligación que tiene la misma Iglesia de integrar todos. Se basa en el discernimiento teológico de las palabras de Jesús: "Padre santo, cuida en tu nombre a los que me has dado, para que sean uno como nosotros" [...] "para que todos sean uno. Como tú, Padre, en mí y yo en ti, que ellos también sean uno en nosotros para que el mundo crea que tú me has enviado" (Jn. 17, 11 y 17,21), como una necesidad urgente. Por eso, la unidad del cuerpo de Cristo es esencial, respecto a la obediencia a Jesucristo y para la misión profética y evangelizadora de todas las Iglesias. En definitiva, fue precursor del ecumenismo entre las Iglesias protestantes en un momento complicado y adverso para todos. Bonhöeffer, como hombre de conciencia va a luchar individualmente contra otrora superioridad de dramáticas situaciones de índole coactivo que le exigirán una prueba de su decisión ${ }^{77}$. Es luchar contra toda barbarie, surja de donde venga y con

${ }^{76}$ Cf. http://www.aica.org/44176-la-actuacion-de-los-obispos-alemanes-durante-segunda-guerra-mundial.html Visto 30-04-2020.

${ }^{77}$ Cf. D. BonHÖEFFER, Resistencia y sumisión, Salamanca 1983, 14-15. 
todos los medios a su alcance. Ante una situación espeluznante de la realidad política, social y moral, ve la necesidad de oponerse al mal en su visión más loable y amplia posible. Bonhöeffer verá la necesidad de acusar a la Iglesia de su tiempo, porque se ha quedado a la defensiva y en justificaciones vacuas, en vez de asumir su auténtica misión: buscar el servicio al hombre y empuñar la justicia. Reiterará que la Iglesia es solo Iglesia cuando es para los demás ${ }^{78}$.

Dietrich Bonhöeffer, va a configurar al hombre desde Cristo y solo tiene sentido desde Él: "La figura de Jesucristo se configura en el hombre. El hombre no adquiere una figura propia, autónoma, sino que lo que le confiere figura y le mantiene en la nueva figura es solamente la figura del mismo Jesucristo. No se trata por consiguiente de una imitación, de una reproducción de su figura, sino que su propia figura se configura en el hombre"79. Hay que seguir Gal. 4,19. Donde Pablo aserta: “iHijos míos!, por quienes sufro de nuevo dolores de parto, hasta ver a Cristo formado en vosotros". Es la incorporación a la figura, a la persona de Cristo, que se hizo hombre en la encarnación, fue crucificado, murió y resucitó. Cristo es, en definitiva, el que nos configura con Él. Pues es Cristo el encarnado, el crucificado y el resucitado. Por eso insiste denodadamente: "El cristianismo habla del único camino de Dios al hombre, del amor misericordioso de Dios a los hombres inicuos y pecadores”, y “¿qué tiene esto que ver con la ética que habla del camino del hombre a Dios?". Porque siempre "el cristianismo habla de la gracia, la ética de la rectitud" 80 . Ante toda esta línea de pensamiento al final Bonhöeffer, mantendrá que "Cristo sufre en representación del mundo. Solo su sufrimiento es un sufrimiento redentor. Pero también la Iglesia sabe ahora que el sufrimiento del mundo busca a alguno que lo lleve. De forma que, en el seguimiento de Cristo, el sufrimiento recae sobre la Iglesia y ella lo lleva, siendo llevada al mismo tiempo por Cristo. La Iglesia de Jesucristo representa al mundo ante Dios en la medida que sigue a su Señor cargando con la cruz $^{81}$.

${ }^{78}$ Cf. D. BonhöEFFER, Resistencia y sumisión, Salamanca 1983, 266-267.

${ }^{79}$ Cf. D. BonhöEfFer, Ética, Madrid 2000, p. 79.

${ }^{80}$ Cf. E.H. Robertson, Dietrich Bonhöeffer, Introducción a su Pensamiento Teológico, El Paso (Texas) 1975, 64.

${ }^{81}$ Cf. D. BonhöEFFER, El precio de la gracia. El seguimiento, Salamanca 1986, 55. 
Para Bonhöeffer, es erróneo comprender la resurrección de Cristo como realidad ontológica, es decir, algo que de verdad sucedió en la historia. No fue un acto propiamente histórico en el sentido experiencial de la palabra. Es más, la expresión, Cristo resucitó y está presente, entendida ontológicamente, representa la superación de toda la unidad de la Escritura $^{82}$. La resurrección del Señor, acontece en el tiempo, pero supera el tiempo, está más allá del tiempo. Es meta histórica, por decirlo así supera las coordenadas espacio-temporales a los que todos quedamos sometidos.

Para Bonhöeffer, como persona, era un hombre digno de toda consideración y de admiración: el sentido de su personalidad, su sensibilidad, su fuerza, su valentía, su capacidad de comprensión y respeto, su audacia vital, la sensibilidad para detectar las dificultades, su fuerza para no callar los atropellos, la denuncia ante el mal. La necesidad de lucha y compromiso social y político que desarrolla con gran énfasis para plantear los más altos ideales, en orden a conseguir de una sociedad fragmentada otra totalmente libre.

Para Bonhöeffer, el evangelio debe ser anunciado, proclamado y asumido de tal forma que se debe preservar lo que es el misterio de la presencia del Señor, en el mundo y en la Iglesia. Este misterio supone compartir desde la fe, la espera del Jesús, desde la oración al Espíritu y de aquí la llamada a la acción. Tal acción debe estar enmarcada por el testimonio activo, real, auténtico y desbordante, y en él, la Iglesia debe estar preparada para ser asumida y dirigida por la Palabra de Dios y la llegada del Espíritu Santo. Para ello será necesaria la gracia.

Para Bonhöeffer, es determinante no percibir a Dios como alguien que resuelve las dificultades de las personas: "Veo de nuevo con toda claridad que no debemos utilizar a Dios como tapa agujeros de nuestro conocimiento imperfecto. Porque entonces, si los límites del conocimiento van retrocediendo cada vez más -lo cual, objetivamente, es inevitable-, Dios es desplazado continuamente junto con ellos y por consiguiente se halla en una constante retirada. Hemos de hallar a Dios en las cosas que conocemos, y no en las que ignoramos" $"$.

${ }^{82}$ Cf. D. BonhöEFFER, El precio de la gracia. El seguimiento, Salamanca 1986, 164.

${ }^{83}$ Cf. D. BonhöEfFer, Resistencia y sumisión, Salamanca 1983, 218. 
Para Bonhöeffer, conocer a Dios a partir de su Hijo abandonado por Él, en el Calvario, supone una nueva y esplendorosa revolución. Algo inaudito incluso en la historia de las religiones: "El Dios que nos hace vivir en el mundo sin la hipótesis de trabajo Dios, es el Dios ante el cual nos hallamos constantemente. Ante Dios y con Dios vivimos sin Dios. Dios, clavado en la cruz, permite que lo echen del mundo. Dios es impotente y débil en el mundo, y precisamente solo así está Dios con nosotros y nos ayuda. Mt 8,17 indica claramente que Cristo no nos ayuda por su omnipotencia, sino por su debilidad y por sus sufrimientos. Esta es la diferencia decisiva con respecto a todas las demás religiones. La religiosidad humana remite al hombre, en su necesidad, al poder de Dios en el mundo: así Dios es el deus ex machina. Pero la Biblia lo remite a la debilidad y al sufrimiento de Dios; solo el Dios sufriente puede ayudarnos" $"$.

Para Bonhöeffer, "la unidad del Espíritu es una síntesis originaria querida por Dios. No es una relación que haya que crear, sino que ya está establecida, aunque se mantiene fuera de lo visible" ${ }^{85}$.

De otra parte, desde la dimensión trinitaria agustiniana, la comunidad divina dentro de la Deidad no deriva de una causa impersonal o instrumental, una ley o un mecanismo, sino de la naturaleza de Dios, que es amor. En este sentido Agustín usa la imagen del Amante, el Amado y el Amor para referirse a la Trinidad: "Heme aquí, yo que busco, cuando amo algo, existen tres cosas: yo, lo que amo y el amor. No amo el amor, sino amo al amante; porque donde nada se ama no hay amor. Luego son tres los elementos: el que ama, lo que se ama y el amor. Mas ¿qué decir si solo a mí mismo me amo? ¿No serán entonces dos: lo que amo y el amor? Cuando uno se ama a sí mismo, el que ama y lo que ama se identifican, como se identifican también el amar y el ser amado cuando uno se ama a sí mismo. Cuando se dice que se ama y es amado por sí mismo, se repite la misma cosa dos veces. Entonces no son dos realidades amar y ser amado, como tampoco son dos cosas diferentes el amante y el amado. Mas el amor y el objeto amado son también aquí dos realidades distintas. Amarse a sí mismo no es amor, si no se ama el amor. Una cosa es amarse a sí mismo y otra amar su amor. No se ama el amor sino cuando se ama;

${ }^{84}$ Cf. D. Bonhöeffer, Resistencia y sumisión, Salamanca 1983, 252-253.

${ }^{85}$ Cf. D. BonhöEfFer, Vida en comunidad, Salamanca 1985, 118-120. 
porque cuando no se ama, no hay amor, En consecuencia, cuando uno se ama a sí mismo, hay dos realidades en él: el amor y el objeto amado. Y entonces el que ama y el amado son uno" $"$.

Así, se entiende que la lógica pericorética es la lógica de la complementariedad, de la reciprocidad dialógica, de la circularidad e inclusión Trinitaria: "En Dios, empero, nada se afirma según el accidente, porque nada mudable hay en Él; no obstante, no todo cuanto de Él se enuncia se dice según la substancia. Se habla a veces de Dios según la relación (ad aliquid). El Padre dice relación al Hijo, y el Hijo dice relación al Padre, y esta relación no es accidente, porque uno siempre es Padre y el otro siempre es Hijo; y no como si dijéramos que desde que existe el Hijo no puede dejar de ser Hijo, y el Padre no puede dejar de ser Padre, sino a parte antea, es decir, que el Hijo siempre es Hijo y nunca principio a ser Hijo. Porque si conociese principio o alguna vez dejase de ser Hijo, sería esta denominación accidental. Y si el Padre fuera Padre con relación a sí mismo y no con relación al Hijo, y el Hijo dijese habitud a sí mismo y no al Padre, la palabra Padre y el término Hijo serían substanciales. Mas, como el Padre es Padre por tener un Hijo, y el Hijo es Hijo porque tiene un Padre, estas relaciones no son según la substancia, porque cada una de estas personas divinas no dice habitud a sí misma, sino a otra persona o también entre sí; más tampoco se ha de afirmar que las relaciones sean en la Trinidad accidentes, porque el ser Padre y el ser Hijo es en ellos eterno e inconmutable. En consecuencia, aunque sean cosas diversas ser Padre y ser Hijo, no es esencia distinta; porque estos nombres se dicen no según la substancia, sino según lo relativo; y lo relativo no es accidente, pues no es mudable" ${ }^{87}$. De aquí se infiere que, la comunidad divina es principalmente una unidad pericorética de Amor.

Por último, para Bonhöeffer, anuncia una fidelidad y, a la vez, un entusiasmo ante las cosas, pues contra lo que supone la antigua escolástica no están separadas de Dios. En vez de afirmar dos áreas de influencia, una sagrada y otra profana y al parecer no cristiana, Dietrich Bonhöeffer postula una realidad penúltima, tan valiosa que, en ella Dios es dado en el mundo, con el mundo y para el mundo, aunque sin identificarse con el

\footnotetext{
${ }^{86}$ Cf. San Agustín, De Trinitate IX, 2, 2: PL 42, 961-962.

${ }^{87}$ Cf. SAn Agustín, De Trinitate V, 5, 6: PL 42, 913-914.
} 
mundo. Desde su pensamiento acerca de la secularización, afirma que la religión como fenómeno es históricamente transitorio, y que, de manera irrefrenable, nos encaminamos hacia un tiempo enteramente no religioso. Realmente su pensamiento no solo ha permanecido, sino que se ha hondado profundamente.

\section{Balance}

Ante Dietrich Bonhöeffer, es necesario tener en cuenta los acontecimientos que van sucediendo en su vida. La conferencia Barmen ${ }^{88}$, donde se dilucida la necesidad de la unión de las Iglesias, respecto a la acción de los Cristianos Alemanes, que determina la acción de la Iglesia Confesante. Esto había provocado claramente la percepción de cómo el nacionalsocialismo había penetrado, sin fisuras, en las estructuras y en los fieles del protestantismo alemán. Muy influido por las posturas teológicas de Karl Barth, van a ser determinantes en su quehacer teológico, aunque era más liberal. Para Bonhöeffer, Dios actúa sobre la existencia humana de forma libre, imprevisible y gratuita, es decir, la fe, juega un papel fundamental. Bonhöeffer analiza sobre todo el fenómeno transitorio e insuficiente de la religión, porque la realidad del hombre como la del mundo y la de Dios alcanzan su nivel máximo de perfección: el hombre, porque llega a la mayoría de edad; el mundo porque alcanza su autonomía y Dios porque desaparece del contenido de la experiencia vital, pero queda en la existencia formal. Por eso aparece una inversión antropológica de la teología que desarrolla la kénosis como identificación con Cristo. No obstante, el sutil pensamiento del teólogo se mantiene con una profunda influencia de Barth y Niemöller. Bonhöeffer, no se le puede separar de los sucesos y las circunstancias más influyentes de la primera mitad del siglo XX. Hay que verle y tratarle desde el singular trasfondo de toda su realidad personal para poder entenderle en sentido amplio.

${ }^{88}$ La Declaración de Barmen constituye el pronunciamiento teológico del primer sínodo de la Iglesia Confesante llevado a cabo en la ciudad de Barmen desde el 29 al 31 de mayo de 1934. EI sínodo congregó 139 delegados de 18 iglesias territoriales, y su declaración se convirtió en el primer pronunciamiento conjunto después de la Reforma entre calvinistas, luteranos y unidos. Repudiando el programa de los Cristianos Alemanes, como así también la postura teológica de ciertos teólogos luteranos, cada tesis de la declaración comprendía un pasaje bíblico, una confesión positiva, y un rechazo. 
En este contexto es preciso tener en cuenta la apuesta que hace por participar en la Iglesia Confesante y de ahí su incondicional apoyo al sínodo de Barmen. Ante el creciente movimiento de carácter eclesial que da soporte al régimen nacionalsocialista, en la Declaración de dicho sínodo, Bonhöeffer expresa y lo asume: "Condenamos la falsa doctrina, según la cual la Iglesia podría y debería reconocer como fuente de su predicación, fuera de y junto a esta única Palabra de Dios, también a otros acontecimientos y poderes, figuras y verdades, como revelación de Dios" 89 . Toda su trayectoria emerge y resplandece dentro de las tinieblas que sumergen a las Iglesias de toda Europa en el período de entreguerras. Fue de las figuras con una pujante fidelidad de vida ejemplar, puesto que irradiaron a Cristo, Palabra de Dios, manteniendo a la vez el testimonio limpio, digno y seguro hasta el final de su vida.

Otro de los aspectos que Bonhöeffer mantiene es el tema de la secularidad, y de cómo se puede hablar de Dios, dentro de esa realidad secular. La respuesta desde la visión católica es muy clara y concreta: "Hablar de Dios de un modo secular es hablar de la vida humana con todas sus dimensiones, como recibida de Dios; es reconocer el carácter de vocación o llamada que tiene todo acontecimiento. Ser honestos con Dios es realizar la fe, renunciando a la falsa seguridad de una racionalidad cerrada en sí misma para lanzarnos a la aventura de vivir según el espíritu de Cristo, que se entregó a sí mismo para la salvación del mundo" ".0 . La dignidad de Bonhöeffer reside en su testimonio personal, pues es de suma importancia, no solo por sus ideas, sino también por su ejemplo al dar su vida por su fe.

Sobre el tema de la religión, Bonhöeffer, "al hablar de religión, en sentido literal, no solo no critica la religión, sino que toda la tarea de su vida será la de un hombre profundamente religioso, es decir, religado y entregado a Dios, que sentía preocupación por establecer el Reino de Dios en estos hombres y en este mundo sin religión"91. 340-341.

${ }^{89}$ Cf. H. VAll, Iglesia e ideología nazi. El sínodo de Barmen 1934, Salamanca 1976,

${ }^{90}$ Cf. J. L. Illanes, Hablar de Dios, Madrid 1969, 200.

${ }^{91}$ Cf. A. Villalmonte, "El cristianismo ¿es una religión?”, en Salmanticensis 16 (1969) 181-199: citado p. 188. 
Respecto al tema religioso, tiene otros aspectos como el tema de la oración, que engarza con la voluntad de Dios. Así recoge su visión experiencial: "Puedo rezar para que se cumpla la voluntad de aquel que sabe lo que necesito antes de que se lo pida. Mi oración es segura, fuerte y pura, solo cuando procede de la voluntad de Jesús. Entonces, la oración es realmente una súplica. El niño suplica a su padre, a quien conoce. La esencia de la oración cristiana no es una adoración general, sino la súplica. A la actitud del hombre ante Dios corresponde el suplicar, con las manos extendidas, a aquel del que sabe que tiene un corazón paternal"92. De esta manera logró amalgamar en su personalidad una unidad de espíritu superior y a la vez, un corazón sensible, con una herencia social indestructible que pudiera quedar un tanto adormecida, pero que no se pierde nunca para toda la humanidad. Bonhöeffer aprovechaba todo el tiempo disponible, amplio en la cárcel al menos al principio, y además, la soledad para crecer en pensamiento y memoria. La personalidad de Bonhöeffer sigue siendo un gran desafío, desde el nivel teológico al de la pastoral, pues su vida autentificó el compromiso de su fe con el prójimo. Por eso su vida demostraría su testimonio como seguidor del Señor Jesús. Sus convicciones sobre el valor cristiano de lo humano y lo divino, lo veía desde su maestro, porque para él, Cristo es el hombre para los otros.

Para Bonhöeffer, la ley de Dios es una expresión del carácter de Dios y Él es inmutable. La única manera de conocer la voluntad de Dios es mediante el estudio de las Escrituras que contienen la ley de Dios. Nunca puede haber una contradicción entre la ley de Dios y la voluntad de Dios. De hecho, afirmará que en la Sagrada Escritura se contempla la verdad religiosa, pero no científica ni histórica. De hecho, tanto Bonhöeffer como Barth, no aceptan la apologética, pues trasgrede los límites que diferencian los dominios empíricos y trascendentales. Se convertirá en un crítico de la interpretación religiosa de la fe.

Desde el punto de vista de Bonhöeffer, cuando la Iglesia vive para sí misma, como suele suceder, niega su existencia, su razón de ser y diluye su identidad quedando solo en una organización religiosa sin influencia ni testimonio. Cuando la Iglesia vive para el mundo encuentra su vocación y reafirma su identidad con el Cristo vivo y solo así, Cristo se hace pre-

${ }^{92}$ Cf. D. BonhöEfFEr, El precio de la gracia. El seguimiento, Salamanca 1986, 106. 
sente en el mundo por cuanto la iglesia se asume a sí misma como cuerpo de Él. Son dos dimensiones muy diferentes. De aquí aparecen una de sus exigentes reflexiones: "La gracia barata es la gracia sin seguimiento de Cristo, la gracia sin cruz...la gracia es cara porque le ha costado cara a Dios, porque le ha costado la vida de su Hijo, y porque lo que le ha costado caro a Dios no puede resultarnos barato a nosotros"93. Bonhöeffer, siempre anduvo desde la recta razón y con la oración. Intenta reflexionar sobre cómo llevar el evangelio a cada clase social, se pregunta sobre la relación entre mundo y Dios: "La tierra es nuestra madre, como Dios es nuestro padre, y pone en brazos del padre únicamente al que permanece fiel a su madre" $"$.

\section{Conclusión}

En primer lugar, Bonhöeffer, fue quien se desempeñó activamente contra la tiranía del Nacionalsocialismo alemán: fue encarcelado y posteriormente asesinado.

En segundo lugar, Bonhöeffer, estudió y profundizó en la teología, especialmente la cristología y la eclesiología, sin dejar de lado el tema de la gracia y la escatología.

En tercer lugar, Bonhöeffer a través de su corta existencia y la gran labor escrita fue una persona que vivió profundamente el testimonio de su fe en Jesucristo.

En cuarto lugar, Bonhöeffer hizo una opción muy decidida a favor de la dignidad de las personas, de cualquier condición que tuviese, especialmente con los judíos.

En quinto lugar, Bonhöeffer, desde su visión de la vida y su audaz pensamiento, consiguió hacer visible y viable un cristianismo comprometido socialmente.

En sexto lugar, Bonhöeffer la radicalidad de su existencia planteó una opción de vida desde el Evangelio en el seguimiento del Señor Jesús.

En séptimo lugar, Bonhöeffer desde la experiencia de su realidad, va marcando el estilo, la manera y la forma de proceder en todo momento.

\footnotetext{
${ }^{93}$ Cf. D. BonhÖEFFER, El precio de la gracia. El seguimiento, Salamanca 1986, 16-17.

${ }^{94}$ Cf. G. Hourdin, Bonhöeffer. Una Iglesia para mañana, Madrid 1972, 64.
} 
En octavo lugar, Bonhöeffer lleva adelante un pensamiento social, impregnado de la teología y su teología se puede llamar de la realidad.

En noveno lugar, Bonhöeffer desarrolla su existencia en el marco de una realidad política muy determinada que es la de Alemania de los años treinta.

En décimo lugar, Bonhöeffer lleva como marca de agua, un extraordinario legado de carácter excepcional como es la visión del compromiso ético.

Las obras de Bonhöeffer han impactado al saber teológico, dado que en ellas desarrolla una visión crítica de las instituciones eclesiásticas cristianas. Un buen número de teólogos cristianos posteriores a Bonhöeffer han hecho sumo hincapié en cómo construir una teología para una nueva sociedad. Pone las bases para desacralizar el mundo. El mundo no es Dios; la naturaleza no es Dios, la política no es Dios, los símbolos religiosos no son Dios. Muchas vidas, entre ellas la de Dietrich Bonhöeffer, han ayudado a soportar el caudal de horror del siglo XX, demostrando que el compromiso, el coraje y la valentía, no son ideas románticas, sino virtudes que se hacen vida y se mantienen en la memoria como verdaderos signos de esperanza y compromiso para todos los hombres. De aquí, que tratase de aceptar y asumir la vida y la obra de Jesús mediante el aprendizaje de su imitación y seguimiento para seguir sus mismos pasos. Se trata de un encuentro consigo mismo. Tomará conciencia del tema que será esencial en su manera de pensar que no será otro que la misma Iglesia. Bonhöeffer, manifestará con palabras rotundas la confianza en la promesa de Dios, pues donde unos solo ven el fin, otros ven el inicio desde la plena libertad y cada uno tendrá que asumir dicha libertad. 